REGARDS

SUR L'ECONOMIE ALLEMANDE

BULLETIN ECONOMIQUE DU CIRAC

\section{Regards sur l'économie allemande}

Bulletin économique du CIRAC

$89 \mid 2008$

Varia

\title{
Management stratégique
}

ESCHENBACH Rolf, ESCHENBACH Sebastian, KUNESCH Hermann, Strategische Konzepte. Ideen und Instrumente von Igor Ansoff bis Hans Ulrich

\section{(2) OpenEdition}

1 Journals

Édition électronique

URL : http://journals.openedition.org/rea/3103

DOI : 10.4000/rea.3103

ISBN : 978-2-8218-0874-4

ISSN : 1965-0787

Éditeur

CIRAC

Édition imprimée

Date de publication : 1 décembre 2008

ISSN : 1156-8992

Référence électronique

"Management stratégique», Regards sur l'économie allemande [En ligne], 89 | décembre 2008, mis en

ligne le 13 janvier 2009, consulté le 22 septembre 2020. URL : http://journals.openedition.org/rea/ 3103 ; DOl : https://doi.org/10.4000/rea.3103

Ce document a été généré automatiquement le 22 septembre 2020.

(c) CIRAC 


\section{Management stratégique}

ESCHENBACH Rolf, ESCHENBACH Sebastian, KUNESCH Hermann, Strategische Konzepte. Ideen und Instrumente von Igor Ansoff bis Hans Ulrich

\section{RÉFÉRENCE}

\section{ESCHENBACH Rolf, ESCHENBACH Sebastian, KUNESCH Hermann, Strategische}

Konzepte. Ideen und Instrumente von Igor Ansoff bis Hans Ulrich, $5^{\mathrm{e}}$ édition, Schäffer Poeschel Verlag, Stuttgart, 2008, 300 p.

1 La stratégie d'une entreprise est la clé de son succès, si et seulement si cette dernière s'accompagne de l'instauration d'objectifs concrets et quantifiables. Afin de s'orienter dans la pléthore des concepts stratégiques développés dans la seconde moitié du XX ${ }^{\mathrm{e}}$ siècle, ce manuel de management qui en est à sa $5^{5}$ édition établit une typologie de différentes approches dont la renommée dépasse le cadre théorique pour s'inscrire directement dans la pratique managériale. L'ouvrage consacre par exemple un chapitre entier à une interview de Reinhold Würth dont les techniques de management et le succès qu'on leur connaît font par ailleurs l'objet d'une abondante littérature. Responsables d'entreprise et étudiants pourront s'inspirer de cet état des lieux des concepts actuellement les plus en vogue en la matière. (sh) 